\title{
MATR3 wt Allele
}

National Cancer Institute

\section{Source}

National Cancer Institute. MATR3 wt Allele. NCI Thesaurus. Code C88992.

Human MATR3 wild-type allele is located in vicinity of $5 \mathrm{q} 31.2$ and is approximately $84 \mathrm{~kb}$ in length. This allele, which encodes matrin-3 protein, may play a role in the regulation of transcription and the structural integrity of the nuclear matrix. 